\title{
Hydrogeological functioning of the tablecloth of the Midelt Furrow (High Moulouya, MOROCCO)
}

\author{
$H$. IKHMERDI ${ }^{\left(1,{ }^{* 1)}, A . \text { BOUKDIR }^{1}, A . \mathrm{KOSSIR}^{2}, L . \mathrm{ALILI}^{1} \text { and E. BEN-SAID }\right.}{ }^{1}$ \\ (1) FST Béni Mellal/Université Sultane Moulay Slimane, Béni Mellal, Maroc \\ (2)Agence de bassin hydraulique de la Moulouya, Oujda, Maroc
}

\begin{abstract}
The superficial tablecloth of furrow of Midelt belongs to the bowl of High Moulouya which stretches out from the west eastward between the High Atlas in the South and the Medium Atlas west and in the Northeast. The methodology used includes the synthesis of geological data, piezometry, hydrodynamics, hydroclimatology and water quality. This study provides the following results: The flow mode of the water table is general SW to NE on the left bank of the Moulouya river and on the right bank, the flow is from the NW to the SE. The piezometric ratings vary from 1460 to $1780 \mathrm{~m}$. The hydraulic gradient is the order of $2 \%$ on average. The transmissivity is usually about $10-3 \mathrm{~m}^{2} / \mathrm{s}$. the punctual flows can reach $501 / \mathrm{s}$ (case of the drilling $\mathrm{N}^{\circ}$ IRE $879 / 38$ realized in the alluviums of the Outat). The flow provided by the sources from conglomerates and lake limestones of the Plio-Villafranchien is $501 / \mathrm{s}$. The unit of the MioPlio-Quaternary aquifer is fed from the infiltrations of rains, by the wadis which cross the banks of the conglomerates and by the landing of the tablecloths of Lias, Dogger and Cretaceous this feeding is however weak in because of the discontinuity of the formations and the poor permeability of the different levels. From a qualitative point of view the groundwater analysis of the aquifer shows that their overall quality is average to good.
\end{abstract}

Keywords: Hydrogeological Functioning, Midelt Mio-Plio-Quaternary Furrow Tablecloth, upper Moulouya.

Email*ikhmerdi@gmail.com 


\section{Introduction}

The Midelt trench surface water table constitutes a water resource of the foreground at the level of the upper Moulouya basin which is part of the atlasic domain[1], which is characterized by a continental climate, dry and hot in summer, cold and little humid in winter. Average annual precipitation is highly variable and closely related to elevation and exposure. They oscillate $235 \mathrm{~mm}$ at Midelt[2][3].

At the level of the study area, water resources are more and more heavily used for agricultural activities, and the drop in the piezometric level is becoming a cause for concern, particularly in the part of the alluvial aquifer, well known in this sector. This study is based on the analysis of the piezometry and the feeding mode, in relation with the evolution of the samples. Geological, hydrogeological and hydrogeochemical synthesis are used to improve knowledge of this aquifer. The determination of the hydrogeological context of the Midelt trench water table is based on the treatment of the drilling work carried out in the area, surveys of the water points, geological field surveys and climatic data.

\section{Study area}

The superficial sheet of Midelt furrow is part of the Upper Moulouya aquifer (Figure 1) which stretches from west to east between the High Atlas which forms the southern boundary, and the Middle Atlas to the west and northeast. The mole of Aouli and that of Bou Mia separate two depressed corridors, that of Aghbalou N'Serdane-Midelt (Midelt Trench tablecloth) in the South, of direction E-W and that of Itzer in the North of direction SW-NE.

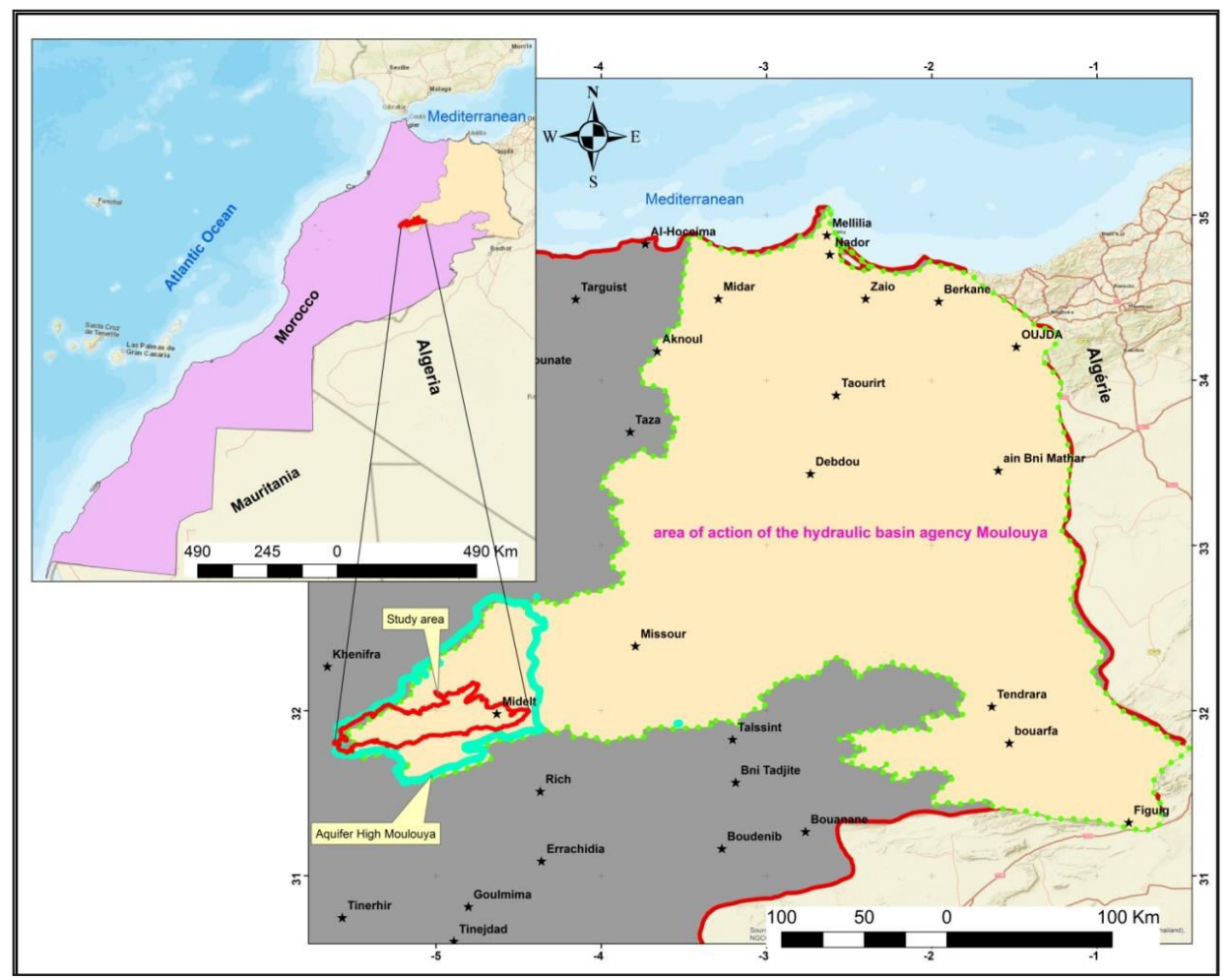

Fig. 1. Geographical location of the study area 


\section{EDE6-2017}

\section{Methodology}

To understand the hydrogeological functioning of the Midelt trench water table, the proposed methodological approach is based on the collection, processing and analysis of all the data related to the following scheme:

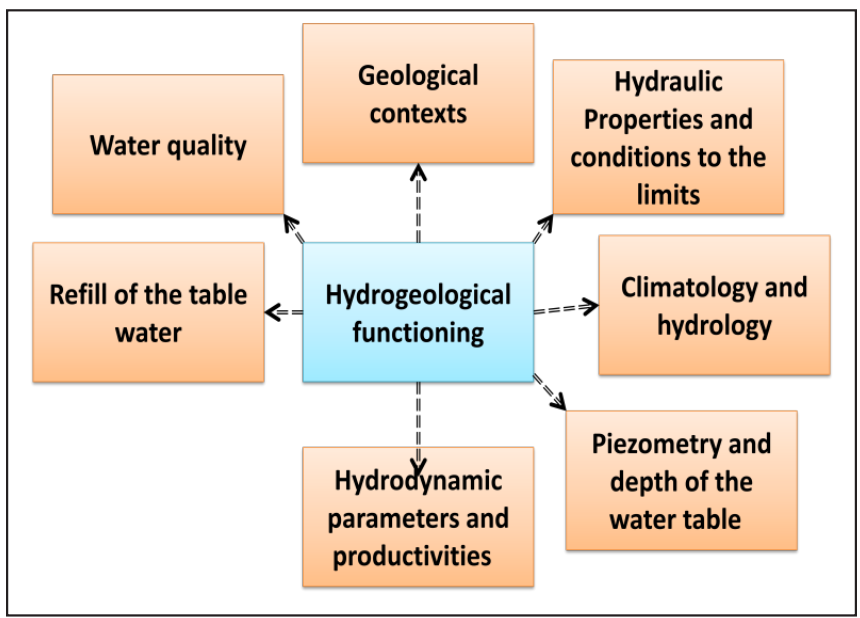

Fig. 2. Hydrogeological operating diagram

\section{Results and Discussions}

\subsection{Aquifer reservoir lithology}

The aquifer reservoir of the Moi-Plio-Quaternary is generally enclosed in Marls, conglomerates, sandstones, sands and lacustrine limestones. In the furrow of Midelt, the quaternary terraces of the valleys may contain large alluvial beds; The alluvial deposits of Oued Outat, Ansegmir, Oudghes, the wadis of the left bank of Upper Moulouya, especially the region of Aghbalou N'Serdane. The thickness of lithological formations can range from 5 to more than $350 \mathrm{~m}$ [1], [4].

To the south of the Midelt Trench nappe and precisely the boundary between the Midelt plain and the High Atlas, the Edge Fault presents an E-W[1] direction, this fault corresponds to the north atlasic accident which limits the entire Midelt plain to the south.

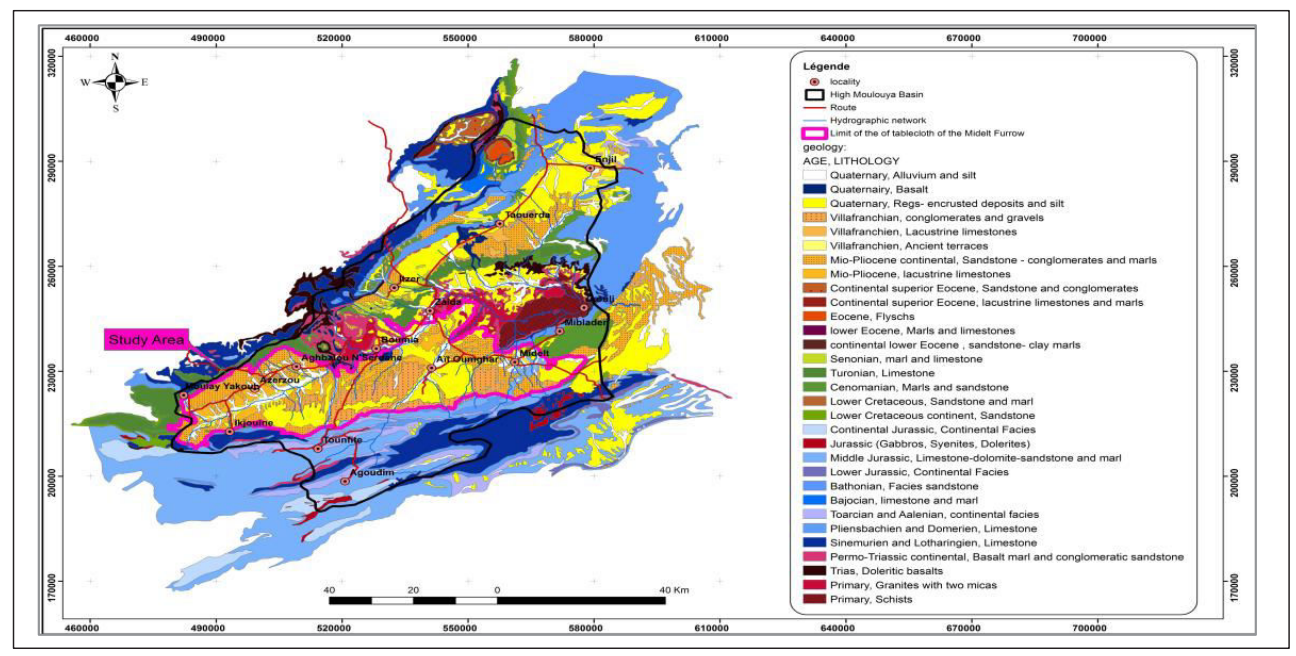

Fig. 3. Geological map of Haute Moulouya (extract from the geological map of Rabat at 1/500000) 


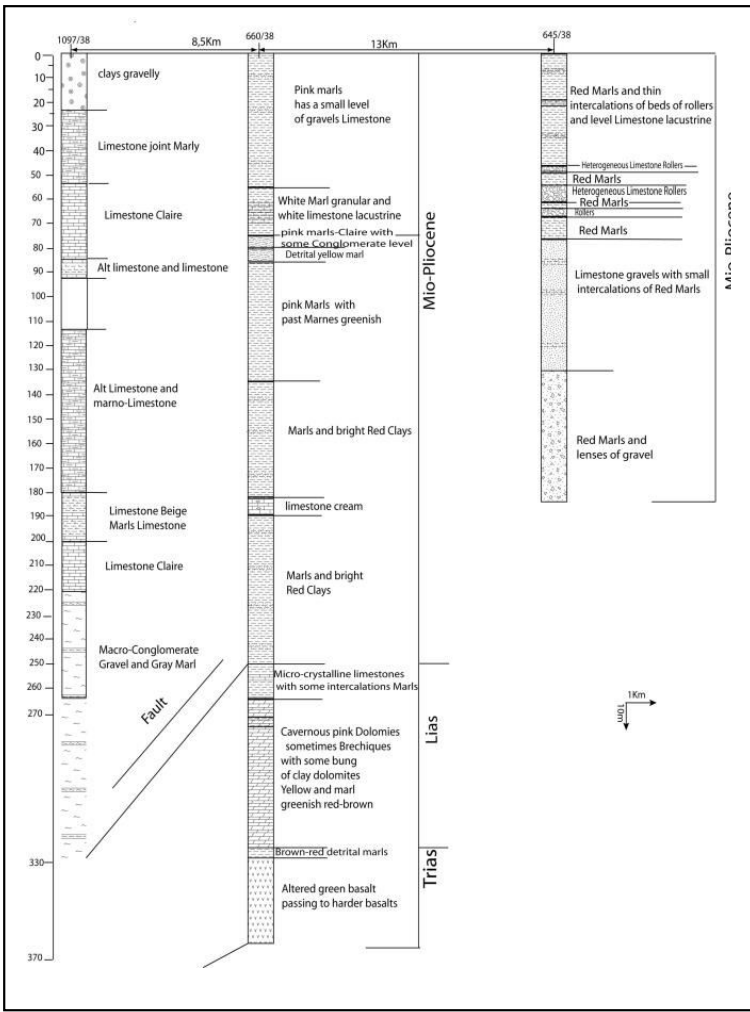

Fig. 4 . Lithological sections of some deep holes drilled in the Moi-Plio-quaternaire Midelt aquifer

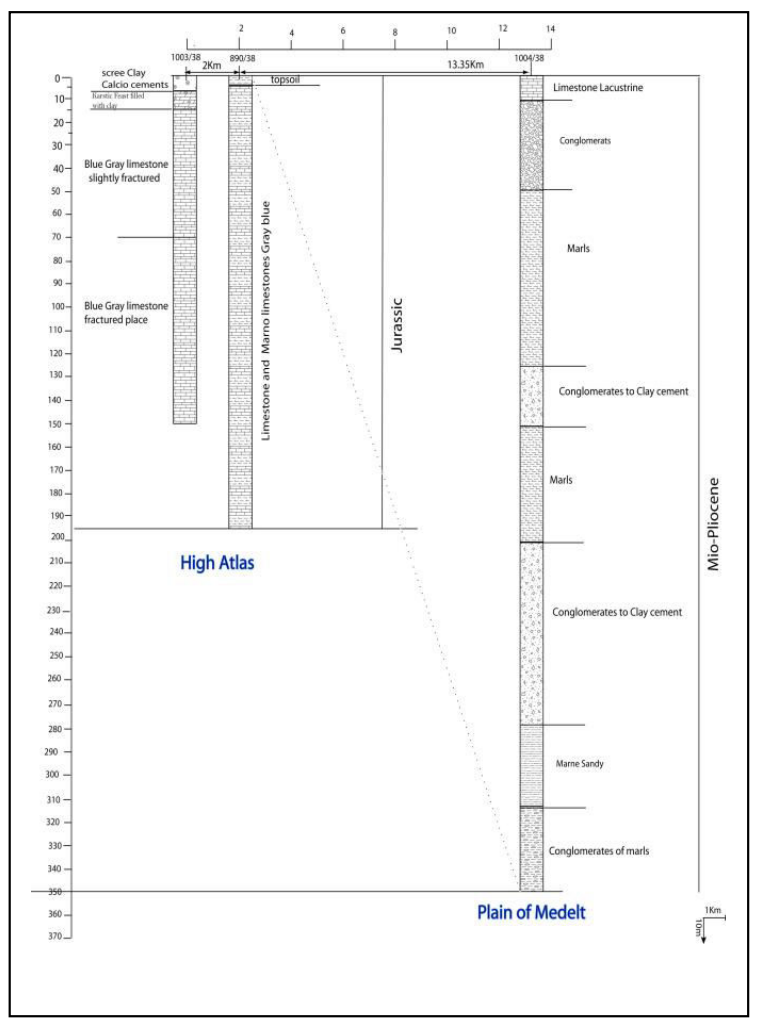

Fig. 5. Lithological sections of some boreholes drilled in the passage zone of the north-high Atlasic accident

Table 1. Characterization of boreholes used in lithological sections

\begin{tabular}{|l|l|l|l|l|l|l|l|l|}
\hline N $^{\circ}$ IRE & X & Y & Z & NATURE & ZLOCALIT_ & P & AQUIFERE & N_P_SOIL \\
\hline $645 / 38$ & 509000 & 229150 & 1640 & FR & Arbal Ou N'serdane & 186,00 & CONGLOMERATES+LIMESTONES & 8,94 \\
\hline $660 / 38$ & 521620 & 227120 & 1770 & FR & Ouest de Midlet & 526,00 & LACUSTRE LIMESTONE & 64,73 \\
\hline $890 / 38$ & 515350 & 210150 & 1900 & FR & TOUNFITE & 194,00 & $\begin{array}{l}\text { LIMESTONE IN MARNO- } \\
\text { LIMESTONE }\end{array}$ & 6,63 \\
\hline $1003 / 38$ & 514550 & 208350 & 1940 & FE & TOUNFIT & 150,00 & LIMESTONE BLUE FRACTURE & 12,76 \\
\hline $1004 / 38$ & 523000 & 221100 & 1800 & FR & AARID & 350,00 & - & 87,11 \\
\hline $1097 / 83$ & 500500 & 229900 & 1765 & FE & Azerzou (ONEP) & 415,00 & & 1,00 \\
\hline
\end{tabular}

From a geological point of view, the study area is characterized by the junction between two domains separated by the north-high Atlasic accident (Fig 4). From a geomorphological point of view, the area is marked by a very rugged topography in the South and slightly flat in the North.

The tectonics of the Tablecloth is characterized by the influence of the atlasic edge (the High Atlas), formed of anticlines WSW-ENE axis faults and straddling to the North [1][3]. According to (Fig.3.4.5) the Substratum of the slick can correspond either to Jurassic or Cretaceous formations, or to the Miocene marly soils. 
A geophysics campaign (1966) made it possible to specify the deep structure of the eastern part of the slick. It highlighted a major fault in the E-W direction at the foot of the High Atlas and collapsing the Lias (Fig 6). The roof of the Lias then forms a vast asymmetrical syncline under the plain, in the same direction as the atlasic accident, and which stops $\mathrm{N}$ on the parallel of Midelt[5][3].

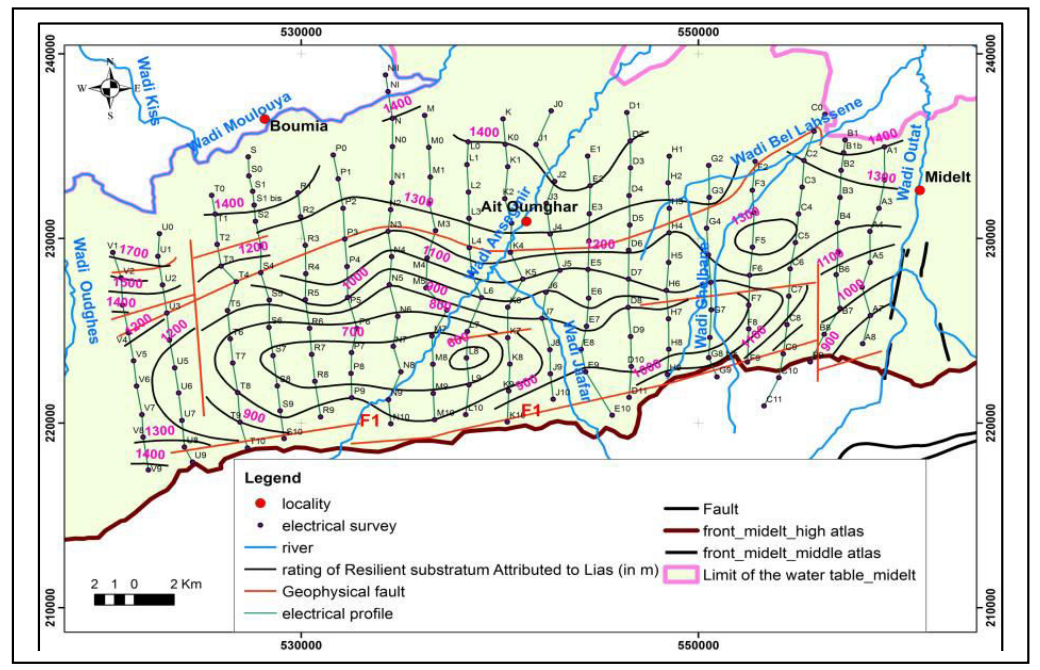

Fig. 6 . Resilient bedrock ratings attributed to Lias limestones (CAG, 1966)

\subsection{Piezometry and depth of the slick}

In the Midelt Trench, the general flow of the entire aquifer unit is from the NW to the SE on the left bank of Moulouya Wadi. On the right bank, the flow is from SW to NE. The hydraulic gradient is about $2 \%$ on average. The piezometric dimensions vary from 1780 to $1460 \mathrm{~m}$.

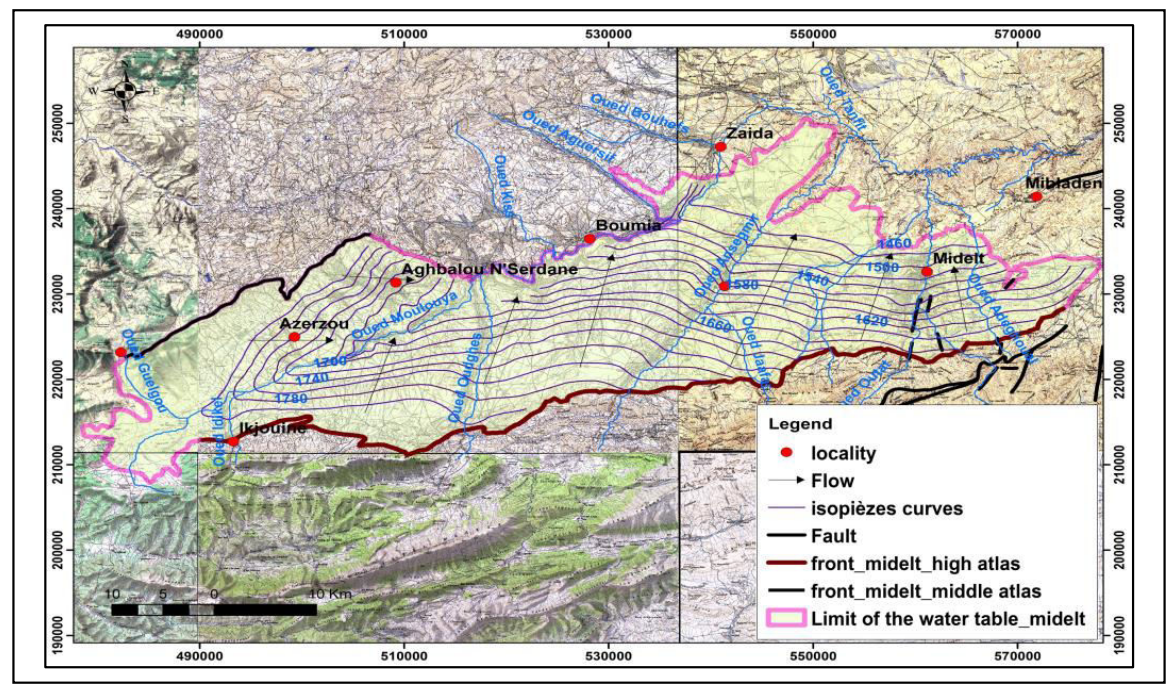

Fig.7. Piezometric map of the Midelt Trench nappe

Piezometric maps which are drawn up for the main alluvial slicks of the Upper Moulouya (Fig 7), show that the flow is generally in the direction parallel to the direction of the wadis which crossed these slicks. The supply of these slicks is very important by the waters of the wadis entering upstream and by the infiltration of precipitations. 


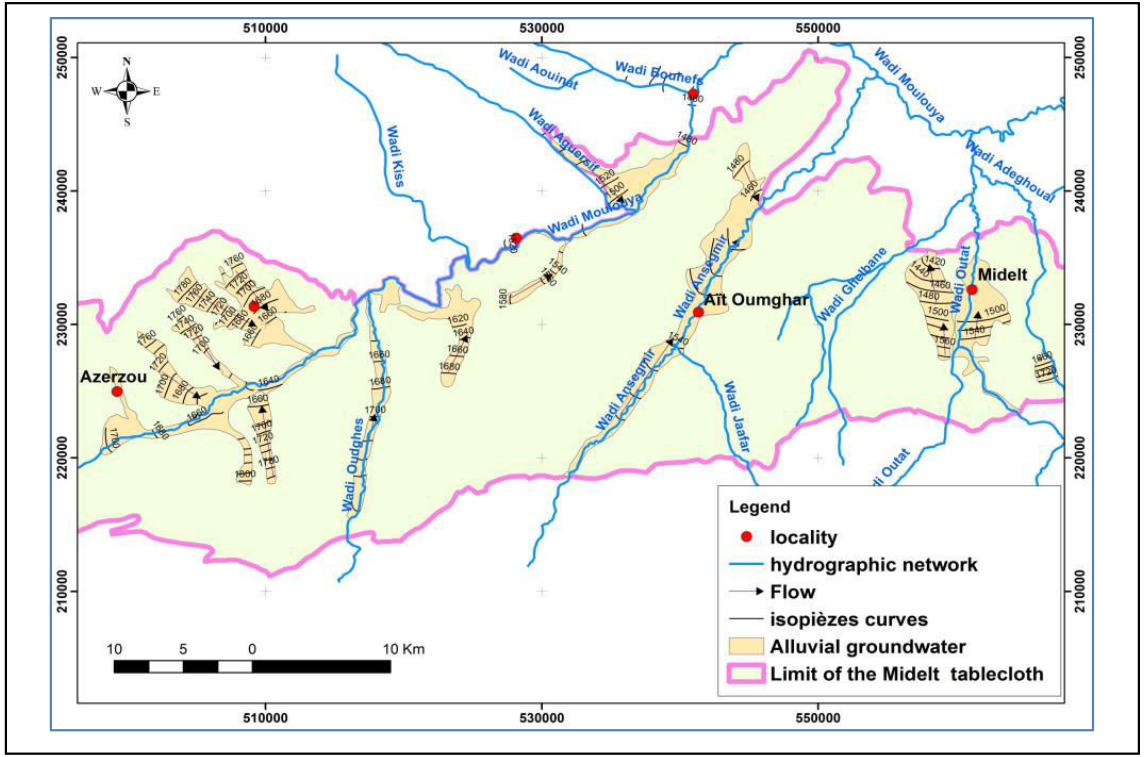

Fig. 8. Piezometric maps of the alluvial slicks of the Midelt plain

\subsection{Hydrodynamic parameters and productivity}

Quaternary alluvial deposits, largely exploited by wells, are discontinuous but have good hydrodynamic and productivity characteristics. The transmissivities are in the order of $10^{-3} \mathrm{~m} 2 / \mathrm{s}$, the punctual flows can reach $50 \mathrm{l} / \mathrm{s}$ (case of drilling $\mathrm{N}^{\circ}$ IRE $879 / 38$ carried out in the alluvium of the Outat).

About ten sources from the Quaternary basaltic formations are located near Bou Mia. They showed low point flows. The available flows are old and do not exceed $5 \mathrm{l} / \mathrm{s}$, the case of the source $\mathrm{N}^{\circ} \mathrm{IRE} 728 / 30$ with a flow of $5 \mathrm{l} / \mathrm{s}$, the source $\mathrm{N}^{\circ}$ IRE 702/30 with a flow of $2.5 \mathrm{l} / \mathrm{s}$ and other sources had very low flows $\left(\mathrm{N}^{\circ}\right.$ IRE $727 / 30$ and 730/30). The flow provided by springs from lake conglomerates and limestones in Plio-Villafranchien is around $50 \mathrm{l} / \mathrm{s}$.

The conglomeratic levels of the Oligo-Miocene are also exploited by numerous wells and some sources of spillage in contact with marl. The flows are generally low (less than 1 l/s), and can give a total flow of nearly $200 \mathrm{l} / \mathrm{s}$. The few boreholes that exploit the Oligo-Miocene aquifer show its poor hydrodynamic characteristics; transmissivities vary between $10^{-5}$ and $10^{-6} \mathrm{~m} 2 / \mathrm{s}$. The flow rates are generally low and oscillate between 1 and $41 / \mathrm{s}$.

In the Aghbalou N'Serdane hydrogeological basin and the Ansegmir zone, the Mio-Plio-Quaternaire slick may have an artesian character [7]; some boreholes ( $\mathrm{N}^{\circ}$ IRE 645/38 and 646/38) are locally artesian due to aquifer loading by marl. Drill hole $N^{\circ}$ IRE 645/38, located south of Aghbalou N'Serdane, crossed marly levels in intercalation with limestone pebbles. It showed an artesian inflow at $60 \mathrm{~m}$ with a low flow not exceeding $0.5 \mathrm{l} / \mathrm{s}$, continuous drilling to a depth of $18 \mathrm{~m}$ and total artesian flow had reached nearly $21 / \mathrm{s}$.

\subsection{Tablecloth supply}

The Mio-Plio-Quaternary aquifer unit is fed from rain infiltrations, by the wadis that intersect the banks of the conglomerates and by the butt of the Lias, Dogger and Cretaceous aquifers. However, feeding is low due to discontinuity of formation and poor permeability of the different levels [3].

The alluvial slick of the Ansegmir wadi, well fed thanks to the outcropping in the major bed of thick pebble formations, is exploited by numerous wells dug in the silty terraces. 


\section{5. Conditions to the limits}

The natural supply of the reservoir is ensured by the lateral contributions coming from the outcrops of the Middle Atlas and the High Atlas overhanging the Midelt Trench. An inflow boundary is drawn along the atlas massifs bordering the Midelt Trench.

\subsection{Quality}

The water points chosen to monitor the quality of the groundwater were chosen so as to have an overall picture of the water table of the Midelt furrow.

Indeed, the measurement of conductivity makes it possible to appreciate the quantity of salts dissolved in water, thus of its mineralization. The values recorded are $1035,1040,804 \mu \mathrm{S} / \mathrm{cm}$, the minimum recorded at well $\mathrm{N}^{\circ}$ IRE $1135 / 38$ and the maximum recorded at well $\mathrm{N}^{\circ}$ IRE $1134 / 38$. The electrical conductivity depends on the loads of endogenous and exogenous organic matter, which generates salts after decomposition and mineralization [6], it also varies according to the geological substrate crossed. At water peaks 1134/38, 1135/38, located near urban centres (Midelt and Aghbalo nsserdan), the EC is generally $1040 \mathrm{pS} / \mathrm{cm}$. This argues in favour of groundwater contamination by infiltration and percolation of leachate water generated by waste [8].

The analyses of the physico-chemical parameters show two groups of chemical elements. The first has dominant levels of $\mathrm{Na}+, \mathrm{Ca} 2+, \mathrm{Mg} 2+, \mathrm{Cl}-\mathrm{NO} 3-, \mathrm{HCO} 3-$ and $\mathrm{SO} 4-$ followed by NH4+, Fe2+,Mn2+, NO2- and CO3-. The richness of water in elements $\mathrm{Na}+, \mathrm{Cl}, \mathrm{Ca} 2+$ and $\mathrm{SO} 42$ 2- is linked to the dissolution of minerals likely to be formed by evaporation of salt-laden water, by dissolution of evaporite formations and dissolution of carbonates [10]. The elements $\mathrm{Ca} 2+, \mathrm{Mg} 2+$ and $\mathrm{HCO} 3-$ on the other hand are linked to the dissolution of carbonates. In a general way, trace elements import information on the origin of waters, their mixtures and contaminations as well as lithological facies [11]. The factors that determine the spatial evolution of trace element contents, of which we can cite: the presence of deep faults, the intensity and load of rainfall, conditions at the Atlas boundary (High Atlas and Middle Atlas) and also depends on the geological substrate through which the water flows.

Table 2. Physico-chemical parameters of groundwater in the Midelt Trench surface water table

\begin{tabular}{|c|c|c|c|c|c|c|c|c|c|c|c|c|c|c|c|}
\hline $\mathbf{N}^{\circ}$ IRE & pH : & $\begin{array}{l}\text { CE : } \\
\mu \mathrm{S} / \mathrm{cm}\end{array}$ & $\begin{array}{l}\begin{array}{l}\text { NH4++ : } \\
(\mathrm{mg} / \mathrm{l})\end{array} \\
\end{array}$ & $\begin{array}{l}\mathrm{Na}+: \\
(\mathrm{mg} / \mathrm{l})\end{array}$ & $\begin{array}{c}\mathrm{K}+: \\
(\mathrm{mg} / \mathrm{l})\end{array}$ & $\begin{array}{l}\text { Ca2+: } \\
(\mathrm{mg} / \mathrm{l})\end{array}$ & $\begin{array}{l}\text { Mg2+: } \\
(\mathrm{mg} / \mathrm{l})\end{array}$ & $\begin{array}{l}\mathrm{Fe} 2+: \\
(\mathrm{mg} / \mathrm{l})\end{array}$ & $\begin{array}{c}\text { Mn2+: } \\
(\mathrm{mg} / \mathrm{l})\end{array}$ & $\begin{array}{c}\text { Cl-: } \\
(\mathrm{mg} / \mathrm{l})\end{array}$ & $\begin{array}{l}\text { NO2- : } \\
(\mathrm{mg} / \mathrm{l})\end{array}$ & $\begin{array}{c}\text { NO3- } \\
:(\mathrm{mg} / \mathrm{l}) \\
\end{array}$ & $\begin{array}{l}\mathrm{HCO3-}- \\
:(\mathrm{mg} / \mathrm{l})\end{array}$ & $\begin{array}{c}\mathrm{CO3}- \\
:(\mathrm{mg} / \mathrm{l}) \\
\end{array}$ & $\begin{array}{c}\text { SO4- } \\
:(\mathrm{mg} / \mathrm{l}) \\
\end{array}$ \\
\hline $1135 / 38$ & 7,20 & 1035 & $<0,007$ & 2,32 & 2,33 & 205 & 50,0 & 0,112 & $<0,014$ & 14,8 & 0,083 & 9,20 & 228 & 0,0 & 524 \\
\hline $1133 / 38$ & 8,40 & 1040 & 0,019 & 85,4 & 1,12 & 106 & 42,0 & 0,237 & $<0,014$ & 138 & 0,091 & 22,0 & 265 & 0,00 & 164 \\
\hline $1134 / 38$ & 7,40 & 804 & $<0,007$ & 30,5 & 7,29 & 111 & 43,0 & 0,068 & $<0,014$ & 67,0 & 0,097 & 38,0 & 421 & 0,0 & 61,0 \\
\hline
\end{tabular}

According to the piper diagram, the wells have a chlorinated and sulphated calcium and magnesium geochemical facies (1133/38) and also bicarbonate and calcium and magnesium (1134/38) (Fig 9). 


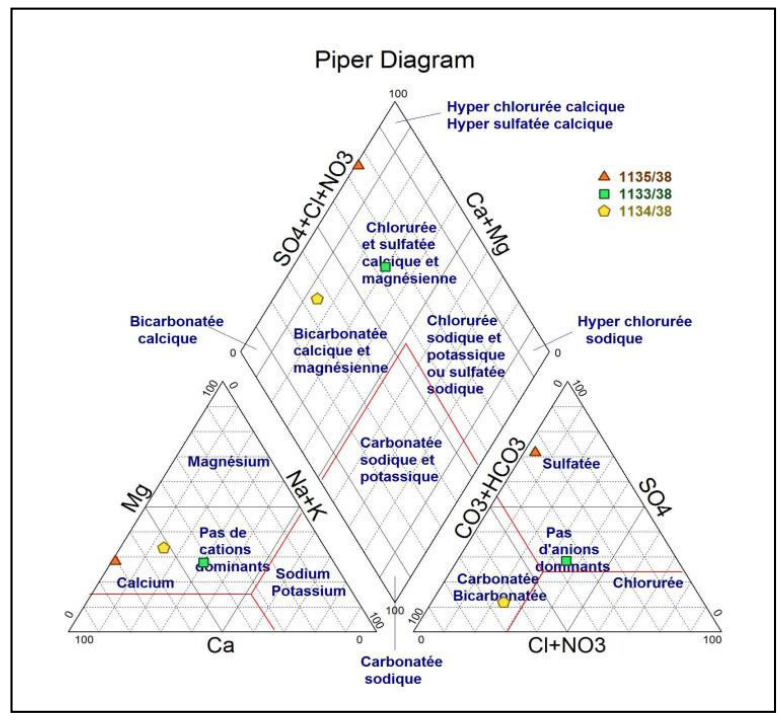

Fig.9. Piper Diagram

\section{Conclusion}

The interest that hydrogeological data (geology, piezometric, hydrodynamic parameters, etc.) may have for the geometrical and structural reconstruction of the Midelt trench. From a hydrogeological point of view, the geometry, the overall structure of the plain and the lithological nature of the formations have a more or less direct influence on the chemistry and renewal of the water table, as also the recharge to an influence on the vertical and lateral groundwater flows of the Mio-Plo-quaternary aquifer. Piezometric analysis of the water table indicates a decrease in recharge and overexploitation of the underground resource, leading to a significant drop in piezometric levels. The physicochemical quality of groundwater is generally average to good compared to Moroccan water standards and criteria (Moroccan Standards, 2002).

\section{Acknowledgements}

We thank the management of the Moulouya Hydraulic Basin Agency for making the data used in this article available to us. We also thank all those who contributed in any way to the development of this work.

\section{Bibliographical references}

[1] A. Michard, Eléments de géologie marocaine (1976).

[2] A. LAABIDI, L. GOURARI, A. HMAIDI, M. AARAB, M. GRETAA. Caractérisation géomorphologique, lithostratigraphique et sédimentologique des dépôts quaternaires de l'Oued Bou Salloum (Haute Moulouya, Maroc), International Journal of Engineering Research and Development e-ISSN: 2278-067X, p-ISSN: 2278-800X, www.ijerd.com Volume 10, Issue 4, PP.07-19, (2014).

[3] Combe, M., \& Simonot, M. "La Haute Moulouya, le sillon d'Itzer et le massif de Boumia-Aouli. Ressources en eaux du Maroc”, Notes et Mémoires du Service de Géologie du Maroc, 213, pp. 193-201, (1975).

[4] A. Amrani. Apport des données couplées d'imagerie satellitaire ETM+ de Landsat 7 et model numérique de terrain appliques a l'étude morphogénétique de la Haute et Moyenne Moulouya (Maroc). Thèse de doctorat es Sci., Univ. Mohamed V-AGDAL, Fac. Sci., Rabat, 216 p (2007).

[5] ABHM, CAG. Étude par prospection électrique dans la haute Moulouya, (1966).

[6] S. Bouchelaghem, S. Benzara, W. Méradi, and R. Souhir. Etude comparative de la qualité chimique et microbiologique des eaux de l'oued El kebir (Région d'El Tarf) International Journal of Innovation and Scientific Research, ISSN 2351-8014 Vol. 3 No, pp. 71-74 (2014). 
[7] ABHM. Étude est l'élaboration des cartes hydrogéologiques des nappes de la Haute Moulouya, de la Moyenne Moulouya et du bassin de Guercif, Mission I : Elaboration des cartes hydrogéologiques de gestion des nappes de la Haute Moulouya et du sillon Itzer-Enjil ; 115P, (2006).

[8] A. BOUKDIR. Fonctionnement Hydrogéologique de L'aquifère du Turonien du Bassin du Tadla-plateau des Phosphates-tassaout Aval (Maroc). Approche Pluridisciplinaire et Etude D'impact - Thèse Doctorat, Université Mohammed v, Ecole Mohammadia des Ingénieurs Rabat, 190pp 116-139, (2007).

[9] K. Baba-Hamed, A. Dribat, A. Bouanani, Hydrogeological Caracterization and Modeling of the Aquifer of Oued in Amguel. (Tamanrasset, Central Hoggar -Ssouth Algeria) Journal of Fundamental and Applied Sciences, ISSN 11129867, 19P, (2018).

[10] M.L. Belghiti, A. Chahlaoui, D. Bengoumi, R.EL MOUSTAine. Etude de la Qualite Physico-chimique et Bacteriologique des Eaux Souterraines de la Nappe Plio-quaternaire Dans la Région de Meknès (Maroc), Larhyss Journal, ISSN 1112-3680, (2013).

[11] M. MAKHOUKH, M.SBAA, A.BERRAHOU, M.VANCLOOSTER. Contribution à l'étude de l'impact d'un site minier abandonné dans la haute Moulouya sur la qualité de l'Oued Moulouya, Maroc, Afrique SCIENCE 07(3), 33 - 48 (2011).

[12] N.M. Norme Marocaine de qualité des eaux. Bull. Off. $n^{\circ}$ 5062, (2002). 